\title{
Financial crisis, contagion, and the British banking system between the world wars
}

\author{
Mark Billings $^{\mathrm{a} *}$ and Forrest Capie ${ }^{\mathrm{b}}$ \\ a Nottingham University Business School, Jubilee Campus, Wollaton Road, \\ Nottingham, NG8 1BB, UK \\ ${ }^{b}$ Cass Business School, 106 Bunhill Row, London, EC1 8TZ, UK
}

\begin{abstract}
In a globalised world, when financial crisis strikes, can countries which are wellintegrated into the world financial system escape? Recent experience suggests not. In the early 1930s, Britain's openness at the centre of the world financial system left it vulnerable, particularly to the central European financial crisis. Yet, there was no financial crisis in Britain in 1931, rather an exchange-rate crisis, and Sterling left the exchange-rate regime of the gold exchange standard. The most important financial institutions, the joint-stock commercial banks, the central part of the payments system, remained robust and contributed to the stability of the British economy.
\end{abstract}

Keywords: globalisation; British banks; the 1930s; contagion; crisis; stability.

preliminary draft: please do not quote without permission of authors

this version: 29 July 2010

\footnotetext{
${ }^{*}$ Corresponding author. Email: mark.billings@ nottingham.ac.uk
} 


\section{Introduction}

The current crisis has given new impetus to research on globalisation, the gold standard, financial crises and contagion in the 1930s. In this article we re-examine the question of financial crisis in Britain in 1931, considering how the financial system might have been at risk. We focus on the banking system, and argue that the major British commercial banks were sound, in contrast to certain merchant banks. For a financial crisis to develop the links between these sectors would need to have been sufficiently strong to threaten the commercial banking system in a way that would have endangered the payments system. But even if this had arisen, the Bank of England ('the Bank') was a mature lender of last resort (LLR), a role it had more or less perfected in the course of the nineteenth century.

We first consider the nature of globalisation and financial crises, and whether there was a 'financial crisis' in Britain in 1931. The next section briefly reviews Britain's interwar economic performance, outlines the Bank's role as LLR and the operation and some criticisms of British commercial banks, and considers the possible spread of 'contagion' to Britain from central Europe. We then review a range of evidence on the main commercial banks in the 1930s, including new material from archival sources. In the final section we discuss and contrast the nature of banking problems in other major countries to those in Britain and draw conclusions.

\section{Globalisation, crisis and British banking}

Globalisation, the increasing integration of markets and economies around the world, sees greater flows of goods, services, capital, and even labour. The economic theory that predicts convergence in trade and factor prices also predicts resistance to the increased openness since the process will produce winners and losers. The outcome depends upon the relative strengths of these groupings and on the prevailing institutional environment. Not surprisingly there are crisis points. 
The current era is sometimes described as one of unprecedented globalisation. An earlier era of globalisation, with its origins in the eighteenth century and its real beginnings in the nineteenth century, is variously argued to have ended with World War One or with the dislocations of the late 1920s and 1930s. The justifiably highly acclaimed analysis of the distinguished historian Harold James argued that the globalisation which began to accelerate around 1870 ended in the years between the two world wars (James, 2001). Many maintain that the end had come with the outbreak of war in 1914, but support for James can be found in, for example, Rajan and Zingales (2003), whose measures of financial development appear to have started falling in the 1930s or 1940s, not recovering to similar levels until 1990.

The First World War was hugely disruptive for trade and capital flows, trade policy, migration, international monetary arrangements and much else. The postwar Treaty of Versailles, which imposed punitive reparation payments on Germany, and squabbling among the allies over the repayment of debts accumulated in the war were damaging to international relations. James argued that globalisation continued until the financial systems of the world crumbled in the Great Depression years between 1929 and 1932. He then suggested that at the end of the twentieth century weak financial systems appeared similar to those of the 1930s and therefore signalled likely doom.

It is vitally important to learn the correct lessons from the past as the current experience of globalisation experiences understandable strains. The essence of the James thesis is that globalisation was brought to a halt as governments struggled to influence their domestic economies in the 1920s and 1930s because '.. financial and banking systems were volatile and vulnerable to panic' (James, 2001, p. 31). We agree with James on the weaknesses in central European finance, but suggest a caveat to an important part of the thesis on '... the vulnerability of the British financial system' (James, 2001, p. 69).

\section{Defining 'financial crisis'}


Taxonomies of 'crises' abound (Kindleberger \& Aliber, 2005, p. 34). We consider that Schwartz (1986) provides the most satisfactory definition of a 'real financial crisis' as circumstances when the money stock is under threat i.e. only when there is a threat to the payments system. A collapse in the money stock in the face of sticky wages and prices leads to a collapse in real output, for which reason growth in the money stock should be preserved. The failure of a large financial institution, or perhaps a major company or municipality, represents a 'pseudo-crisis', which may create problems for shareholders and taxpayers but not threaten the financial system.

The money supply is determined by the actions of the monetary authorities, the banks, and the non-bank public. The latter two hold currency and deposits in certain proportions. When the public fear banking difficulties they move out of bank deposits into currency, and the banks raise their cash reserves to accommodate that demand. Banks in fractional reserve systems take deposits, and make loans, and thereby multiply the stock of money. When banks fail, or take steps to reduce their assets, they reduce the money stock, abrupt falls in which will damage the real economy when wages and prices are sticky. The monetary authorities need to know how to act in these circumstances, and to do so quickly. In the face of a need for liquidity, they must inject the appropriate amount of monetary base into the system to keep the money supply growing at its normal rate given the different ratios now prevailing.

\section{Financial crisis in Britain in 1931?}

At the beginning of the 1930s, against the background of growing international economic and political tensions, the British economy and some financial institutions experienced various problems. These included currency crisis and abandonment of the gold standard, payment difficulties of international borrowers, especially those in Germany and other central European countries, and struggling domestic borrowers in traditional industries. The idea of a financial crisis in Britain in 1931 first entered the economic history literature with an article which confused the different elements of crises and labelled them 'financial crisis' (Williams, 1963). It is still sometimes asserted that there was such a crisis, no doubt partly because financial crises were experienced in many other countries and 'financial crises ricochet from one country to 
another' (Kindleberger \& Aliber, 2005, p. 124). We contend there was no 'financial' or 'banking' crisis in Britain in 1931, a view shared by others (for example, Grossman, 1994; Jonker \& van Zanden, 1995; Kindleberger \& Aliber, 2005; Reinhart \& Rogoff, 2009).

The problems of the 1930s affected the different types of British banking institution to different degrees. Some merchant banks and British-owned banks operating overseas ('British overseas banks') were particularly hard-hit, but the principal commercial banks, the joint-stock clearing banks, proved to be sound. This group of institutions, small in number but of key importance, were the country's largest financial institutions and the core of the payments system. Their performance in the twentieth century has been subject to many criticisms, many of these unjustified or exaggerated. Underlying the debate on their role is an implicit trade-off between stability and risk-taking. We argue that at a time when many of the developed world's banks were in difficulty these banks were in a position of relative strength. This contributed greatly to the stability of Britain's financial system and its economy, still a leading economy in the interwar period, with an important, albeit weakened, currency.

\section{Britain and its banking system}

\section{The interwar British economy}

The picture often presented of interwar Britain is one of unremitting gloom - deflation, exchange-rate shame, the General Strike, unemployment, the Jarrow March, and other such features. Space precludes a comprehensive assessment, but in aggregate the British economy performed well in the interwar period (Crafts, 2004). After the First World War boom GDP per capita fell, but reached its 1913 level again in the mid1920s. The next peak in 1929 was followed by recession, but Britain suffered no Great Depression. Output fell significantly in just one year (1931) and was static in two others between 1929 and 1932, with an overall fall in GDP per capita of around $71 / 2 \%$ from the peak. GDP per capita then rose by more than $22 \%$ from its 1931 level 
in the strongest-ever upswing in British economic history between 1932 and 1937 (Feinstein, 1976, Table 17). The 1930s was the decade of ring roads and 'interwar semis', a huge construction boom and growth in 'new industries'.

Unemployment rose sharply from around 1 million in the 1920 s to peak at around 3 million, then fell quite quickly as economic growth rose sharply in the 1930s, although significant regional variations remained (Hatton, 2004, p. 350, Table 13.1). This unemployment is explained best in terms of rising real wages, the consequence of falling prices, fixed labour contracts, and changes in the benefit system, which encouraged the supply of labour and dampened the demand for it (Beenstock, Capie, \& Griffiths, 1984). The principal explanation for the good performance after 1932 was the abandonment of the gold standard, generally experienced by countries which abandoned (Bernanke \& James, 1991), and the resulting freedom to use monetary policy flexibly, with low interest rates from 1932. This all took place in the face of collapsing international trade to which the British economy was more exposed than most.

Capie, Mills, \& Wood (1986) showed that there was no 'real financial crisis' in 1931, although Sterling suffered an exchange-rate crisis as the pound was forced off the gold standard and the exchange rate declined precipitately in the closing months of that year. The restoration of the gold standard in 1925 had been unsatisfactory in terms of the various rates adopted by different countries in the following few years. The pound was overvalued and pressure mounted on Sterling through the summer of 1931, in large part due to the decline in the capital account of the balance of payments and weak government finances, which led to political crisis and the formation of the National Government (Eichengreen, 1992, pp. 279-285; Williamson, 1992). Reserves were insufficient to sustain the fixed rate without the support of damagingly high interest rates, and the link with gold was broken in September after it became clear that the parity could not be defended.

The Bank of England's lender of last resort role and the commercial banks 
The risk of financial crisis, which would endanger the commercial banks and the payments system, could be averted by appropriate LLR action. In Britain, the Bank was a mature LLR, a role slowly learned in a favourable legislative period and near-toideal institutional setting in the course of the nineteenth century (Capie, 2002). When banks learned that they could always access liquidity they were less inclined to panic as the Bank could inject liquidity as soon as its carefully-attuned antennae detected fears of illiquidity. The operation of the discount houses as a buffer between banks and the Bank allowed anonymity to prevail and prevented special pleading, very much in line with the mood of that time in keeping special interests at a distance. The gold standard was a complicating factor, as the monetary base was determined via the balance of payments. The solution would be to suspend the gold standard when there was the risk of a financial crisis, and supply all the cash needed to satisfy demand. This could be done only where the supplying institution had strong credibility, as the Bank achieved in the nineteenth century, when there was almost complete trust in the system and appreciation of its workings. These arrangements contributed to the remarkable stability of the British financial system from the 1870 s to the late twentieth century. There was no 'real financial crisis' after 1866, although the Bank provided liquidity as LLR on occasions when fear made an appearance. The British system remained stable even when other countries suffered financial crises, such as in 1873 or 1907 . So in 1929-31 the banking system understood how the Bank would behave if panic began to appear - the Bank could supply the markets with all the liquidity needed at an appropriate rate of interest.

The commercial banking system evolved into a highly concentrated one as the Bank's role became more clearly defined and understood. By 1920 the five largest banks dominated. The 'Big Five' were all London-based, held about $80 \%$ of all deposits and had around 10,000 branches. They had learned prudence, were welldiversified across the country geographically and across all sectors of the economy, and had shifted to more liquid asset structures (Collins \& Baker, 2001, 2003), which allowed capital ratios to fall. This system has been subject to long-standing criticisms that the banks were too conservative and failed to: lend to new, small and deserving businesses or to risky ventures; provide long-term capital to support industry; promote industrial restructuring; and charge competitive lending rates or pay competitive 
deposit rates. Additionally the banks are argued to have held excessive amounts of government debt, demanded unreasonable security from borrowers, and used their 'cartel' to enjoy a quiet and comfortable life.

The banks could claim that their role in the provision of finance was expected to be a limited one, but criticisms have persisted, partly due to the banks' failure to contradict them. For example, the banks were so keen to preserve their reputation for sound finance that in their evidence to the 1931 Macmillan Committee they accepted that they did not lend on anything other than a short-term basis, for anything other than working capital. Many studies have shown these criticisms and the contrasts often made to other countries, particularly in continental Europe, to be exaggerated (for fuller discussion of these issues, see, for example, Ackrill \& Hannah, 2001, pp. 93-5; Baker \& Collins, 2010; Collins, 1998; Newton, 2003; Ross, 1996).

\section{Central European problems in 1931 and the German Standstill}

If there was no financial crisis in Britain in 1931, was the banking system nevertheless at risk? James argues that it was threatened by the exposures of those British merchant banks closely linked to continental Europe to the severe liquidity and solvency problems which developed rapidly there in the first half of 1931, a theme recently revisited by Accominotti (2009). The May 1931 insolvency of Credit Anstalt, Austria's largest bank but poorly managed in the 1920s, quickly shifted attention to the closely-connected German universal banks. One of the six large banks, the Darmstädter-und Nationalbank (Danat), failed due to its large exposure to the textile company Nordwolle. The Berlin Great Banks operated on very low cash and reserve ratios, and their total assets and liquidity declined further in June and July 1931 as panic spread and depositors, including those from overseas on whom they relied heavily, withdrew their funds (Eichengreen, 1992, pp. 261-279; Kindleberger, 1986, pp. 144-159; Kindleberger \& Aliber, 2005, pp. 258-262). The Reichsbank, with limited experience as a central bank, failed to behave as the LLR, and to lend freely to the market, although given the practices of the universal banking system and the size of the leading banks it was difficult for it to act (Capie, Mills, \& Wood, 1986). 
The German banks' difficulties and the country's international payment position, against the wider background of World War One reparations and political, economic and social problems, led to a partial moratorium covering much of its international debt. The six-month September 1931 German Credit Agreement ('the German Standstill'), renewed annually from 1932, formalised the position of shortterm debt, much of which arose from trade finance. Approximately $£ 54$ million was initially due to British creditors, around one-third of this to the clearing banks. The smaller merchant banks accounted for most of the remainder, and were therefore proportionately much more heavily exposed (Accominotti, 2009). The international debts of Austria and Hungary were subject to similar arrangements, although British exposures to these were a small fraction of the German Standstill exposures. ${ }^{1}$

German business was a mainstay for the merchant banks with European origins - '... family enterprises linked to much of the rest of the world by "separate" family firms in other countries' (Kobrak, 2009, p. 53). These firms included Kleinworts and Schroders, which had the largest German Standstill exposures respectively three times the partners' capital (Diaper, 1986, p. 68), and approximately 1.3 times partners' capital and bad debt reserves (Roberts, 1992, p. 264). Others with large exposures included Lazards (Forbes, 2000, p. 40), but not all were so heavilyexposed - Morgan Grenfell, for example, had largely avoided private German business (Burk, 1989, p. 85). The Bank, with the Treasury's approval, took the lead role in ensuring British banks remained engaged in the Standstill. It exercised 'moral suasion', asking commercial banks to provide sufficient support to their merchant bank customers to allow them to continue in business (Roberts, 1992, pp. 252-253, 266).

Seen by some as economic appeasement, but by others as pragmatism or resigned realism, the Standstill arrangements represented a compromise between political and financial interests - a means to maintain credit lines to Britain's largest trading partner, to facilitate trade, and sustain economic relations and encourage economic stability in Germany, thereby protecting the creditors' interests against the collapse in international trade and rising protectionism and political tensions (Forbes, 1987, 2000). The result was that British bankers appeared less aggressive than many 
German Standstill creditors in reducing their exposures. By 1939 total credit lines extended by British-based creditors had increased from $24 \%$ to $57 \%$ of the overall total outstanding, which had fallen considerably (Forbes, 2000, p. 193, Tables 7 and 8). But, generally, British bankers accepted the Standstill reluctantly, fearing that the alternatives, such as a complete moratorium, the use of clearing arrangements, or extracting themselves with considerable losses, were worse (Forbes, 1987, p. 586; Kynaston, 1999, pp. 434-435). Ultimate repayment came only after the 1952 Lancaster House conference secured a comprehensive settlement of Germany's preWorld War Two debts, including long-term debts, much of which were owed to US creditors.

\section{The resilience of British commercial banks in the 1930s}

What evidence is there to support our contention that Britain's major commercial or clearing banks demonstrated resilience during the 1930s? Data from secondary sources combined with new archival material provide a reasonably clear picture, but variations in the operations of different banks and the inevitable vagaries in the survival of archival data mean that the same information is not available for all institutions.

\section{Clearing banks' support for the Bank}

The large clearing banks neither needed nor received support from the Bank. Table 1 summarises a number of support operations of various types in the period, the existence and details of which have usually only become known subsequently. The Bank often played a leading role, and virtually all these operations related to merchant banks or British overseas banks. The notable exception was Williams Deacon's, the small Manchester-based clearing bank with a heavy concentration of lending to the cotton industry. Its takeover by the Royal Bank of Scotland was engineered by the Bank, which met those losses which arose prior to the takeover. The Bank bore the bulk of losses from the identified operations, which totalled around $£ 8$ million (a little over $£ 400$ million at end-2009 prices) from Anglo International, Anglo-South 
American Bank (ASAB), Huths, and Williams Deacon's. The clearing banks also incurred some losses. Their involvement in such operations was not new; they had, for example, joined together under the leadership of the Midland Bank and the Bank to support the Yorkshire Penny Bank in 1911 (Holmes \& Green, 1986, pp. 143-147). [INSERT TABLE 1 HERE]

The clearing banks also assisted the Bank's efforts to support Sterling. Barclays entered into an exchange with the Bank, receiving British government Treasury bills for commercial bills, which the Bank then used as security for its August 1931 loan of $£ 25$ million from the Bank of France (Tuke \& Gillman, 1972, p. 31). At the request of the Bank the banks also participated in a scheme in the forward foreign exchange market, and at one of the smaller clearing banks '... the General Manager reported that forward [US] dollars and [French] francs had been sold for account of the Bank of England to the extent of $£ 1,700,000{ }^{2}$. This operation involved about $£ 20$ million of forward sales (Sayers, 1976, pp. 408-409), not insubstantial compared to the Bank’s gold and foreign exchange holdings of $£ 141$ million at 30 December 1931 (Sayers, 1976, Vol. 3, Appendix 37, p. 355), or total UK reserves at the same date, including Treasury holdings, of $£ 210$ million (Howson, 1980, p. 80, Table 3).

\section{Capital flight from Britain and bank deposits}

We noted earlier the reliance of German banks on short-term international deposits. Short-term foreign capital was withdrawn from London during the 1931 exchange-rate crisis (see, for example, James, 1992, pp. 602-603; James, 2001, pp. 71-72; and Williams, 1963, pp. 525-528). Some of this capital flight represented withdrawal of bank deposits, but it is also believed that foreign holdings of securities were liquidated. Estimates of capital outflows are problematic, with contradictory accounts, both as to the identity of the sellers of Sterling and the amounts involved. Although detailed data on foreign depositors' funds at the clearing banks are not available to reconcile the various accounts, the available data do indicate that major British banks were much less reliant on international deposits, did not suffer withdrawals on the same scale, and remained much more liquid. 
The clearing banks' aggregate deposits fell by around $£ 125$ million in calendar year 1931, but by only 4\% from June to September (Capie \& Webber, 1985, pp. 437, 444, Table III.(4) ). Deposits of the Big Five, with stronger London bias to their business, fell more sharply than those of the smaller clearing banks and the Scottish banks (Table 2). Deposits of the merchant banks were small in relative terms, but 'the acceptance houses had $£ 105$ millions of deposits, nearly all of foreign origin’ at the end of 1930 and lost about $40 \%$ of these (Truptil, 1936, p. 314). Deposits in the British overseas banks, typically with distinct geographical biases to their activities, did not generally decline more than those of the clearing banks. The exception was ASAB, whose deposits contracted sharply, reflecting the fears for its future which forced the Bank to organise a major and long-running support operation (see above). [INSERT TABLE 2 HERE]

New archival data for weekly deposit balances throughout 1931 for two clearing banks, one large (Westminster) and one small (District), suggest that variations during the year were not particularly wide (Table 3), although Westminster's deposit balances touched their minimum immediately after gold standard suspension. In Table 4 we report monthly averages of aggregate deposits for the clearing banks in 1931 and in the five years before and after. The range of variation in 1931 was wider than in some years, and the levels of deposits in September and October 1931 a little lower than typical for these months, but the overall data do not indicate major deposit losses around the time of exit from the gold standard. [INSERT TABLES 3 AND 4]

Limited archival evidence from Westminster Bank implies that withdrawals of deposits placed by foreign customers with the clearing banks would have represented only a small proportion of short-term capital outflows in 1931:

When five years ago, England [sic] went off gold, we had approximately $£ 20$ millions of sterling balances from customers domiciled abroad ... by September 1934, such balances were reduced to $£ 171 / 4$ millions ... now the Foreign Sterling Balances 
are at the record figure of $£ 31 \frac{1}{2}$ millions ... This Bank habitually holds more than one fifth of the Foreign Balances deposited with the eleven Clearing Banks. ${ }^{3}$

Foreign currency deposits at the Westminster were small. US dollar deposits and loans were roughly equal at approximately $\$ 11$ million at 31 October 1927 . When German payments were suspended there was a mismatch, very small in relation to the overall balance sheet, with approximately $\$ 14$ million in deposits and $\$ 5$ million in loans at 13 July 1931 , reduced to $\$ 10.5$ million and $\$ 3$ million respectively by 7 September 1931.4

\section{Asset structures}

The clearing banks' aggregate balance sheets for 1930 and 1931 suggest that their deployments of assets were not notably different from earlier decades (see Table 5), although higher proportions of the 'bills discounted' and 'investments' categories were represented by British government debt. In the 'crisis year' of 1931, the clearing banks remained sufficiently liquid to maintain normal business. Despite rumours in May 1931 in the New York market that it was in difficulty (James, 2001, p. 71), archival data show that Barclays continued to make large advances to a wide range of customers before and after the German Standstill and abandonment of the gold standard. $^{5}$ A similar picture of 'business as normal' can be found in the approvals given by Lloyds' Board of Directors. ${ }^{6}$ The major change in the clearing banks' asset structures occurred in 1932 - advances fell in absolute and relative terms, offset by the rise in investments, which consisted almost wholly of British government securities (see Table 5). At every year-end from 1932 to 1939 investments represented between $31 \%$ and $33 \%$ of total assets and advances ranged from $33 \%$ to $37 \%$. [INSERT TABLE 5 HERE]

\section{Profitability and capital}

Previous studies such as Grossman (1994) and Jonker \& van Zanden (1995) relied on published data for the profits and capital of British banks. In this period the banks were not obliged to publish their 'true' positions, which they obscured by various 
means, the most important of which was 'hidden reserves'. The banks used these to smooth fluctuations in performance over the business cycle to help present a picture of strength and stability (Billings \& Capie, 2009). In a recession, when profits were relatively low, they would draw from hidden reserves to report higher profits and at the peak, when profits were relatively high, they would add to hidden reserves, reporting lower profits.

Returns on capital measured using 'true' profits and capital figures were rather more volatile than those the banks published, but, on average, did not deviate dramatically from their reported positions (Capie \& Billings, 2001, pp. 380-381, Tables 2 and 3). Overall the 1930s were less profitable than the 1920s and later decades, except for the Midland Bank, and it was a very rare event for any clearing bank to make a loss on a 'true' basis. Predictably, advances were the most profitable asset category (Capie \& Billings, 2004). Investments were also profitable, and the policy of 'cheap money' from 1932 provided some banks with a useful cushion of unrealised profits on investments (Billings \& Capie, 2007, p. 151, Table 7). Published financial statements consistently understated the strength of clearing banks' capital positions due to significant hidden reserves (Billings \& Capie, 2007, pp. 150-151, Table 6). Calculations based on archival data indicate that 'true' capital ratios deteriorated to some extent through the 1930s, with variations from bank to bank (Table 6). But declines were not sharp, and arguably, given the fall in advances, lower capital ratios were appropriate. [INSERT TABLE 6 HERE]

\section{Bad debts}

Archival sources yield new data on the clearing banks' experiences of bad debts during the interwar period. Three measures are presented in Table 7 where data permit: total bad debt provisions, being the total amount set aside against bad debts at the year-end as a percentage of year-end advances; the annual bad debt charge, being the net new provisions for bad debts as a percentage of year-end advances (negative figures indicate that provisions no longer required exceeded new provisions); and the annual bad debt write-offs, the total amount of bad debts written off in the year as a percentage of year-end advances. Total provisions are almost invariably a multiple of 
the annual charge or write-offs, as banks usually maintain for some time provisions against those debts which they consider might 'go bad', before actually writing off the unrecovered debts. Bad debt provisions are not treated as part of capital in the capital ratios we report in Table 6, so over-provision for bad debts, whether simply misjudgement of the possibility of loss, or deliberate over-provision out of a sense of prudence, could be considered additional capital (see Ackrill \& Hannah, 2001, pp, 448-450, for discussion of issues in the measurement of bad debts). [INSERT TABLE 7 HERE]

Overall, the data do not suggest a marked deterioration in bad debt experience from the 1920s to the 1930s, and reflect levels of bad debt which would be considered low by international comparisons. Although total provisions expressed as a percentage of advances were worse in the 1930s, falls in advances exaggerate this apparent deterioration. New provisions for bad debts were generally lower in the 1930s than in the 1920s, and actual write-offs similar for Barclays, the only bank for which records of write-offs in both decades survive. The reported data include provisions and write-offs for German Standstill debt, and the unusually high 1939 write-off for Barclays reflects its write-off of Standstill debt.

The clearing banks, in common with the merchant and British overseas banks, were not a homogenous group, and the diversity of operations within the sector can be considered a stabilising factor. Barclays, with significant operations in its international subsidiary, Barclays DCO, showed different bad debt experience in its domestic and international operations (Ackrill \& Hannah, 2001, p. 451), suggesting some benefit from diversification. The Midland and Lloyds banks provide additional examples.

The Midland's exposures to British trade and industry were greater than those of other banks, and by 1930 it already had '... a particularly heavy concentration [of doubtful or bad debts] in the textile industry, coal, iron and steel, and in stockbroking and the commodity trades' (Holmes \& Green, 1986, pp. 179 and 189). Its exposure to the Royal Mail Shipping Group, through its Belfast Bank subsidiary, was £3.4 million, roughly equivalent to its initial German Standstill exposure (Holmes \& 
Green, 1986, p. 185). But the Midland suffered few problems from international business, having pursued a different strategy from the other Big Five banks. It had no subsidiary or branch operations outside Britain, but its London-based overseas branch, with an extensive correspondent network, was consistently profitable (Holmes and Green, 1986, p. 165).

In contrast, Lloyds' exposure to heavy industry was relatively low. For example, advances to collieries in July 1931 amounted to only $£ 1.43$ million, less than $0.4 \%$ of assets. $^{7}$ But Lloyds had relatively large indirect exposures to South America and Europe through subsidiaries or associates which it was forced to support. It owned 57\% of the Bank of London and South America (BOLSA) in the early 1930s, diluted to below 50\% after BOLSA's 1936 merger with ASAB, and declined to participate in the support operation for ASAB due to its interest in BOLSA (Jones, 1993, pp. 140, 241). Lloyds' 10\%, £100,000, shareholding in British Italian Corporation generated a loss of more than ten times its original investment (Jones, 1993, pp. 231-234; Table 4). An equal partner in Lloyds and National Provincial Foreign Bank, with its head office in Paris and most of its operations in France, Lloyds shared in providing support of $£ 1.5$ million by the outbreak of World War Two, representing approximately $10 \%$ of the joint venture's total assets at November $1935^{8}$

The clearing banks pursued various approaches to manage their Standstill debts by: bringing non-Standstill German exposures within Standstill arrangements; taking steps to minimise currency losses from exchange-rate volatility after breakdown of the gold standard; and bringing exposures of their international subsidiaries within parent bank arrangements. Some banks realised losses to reduce Standstill exposures, but others allowed the Standstill to take its course, and being well-capitalised could afford to do so. Archival data show that the exposures of Lloyds and National Provincial banks to Standstill debt were lower than those of the other large clearing banks, and the declines in their exposures between 1931 and 1939 reflected greater willingness to accept losses in reducing these (see Table 8). [INSERT TABLE 8 HERE] 


\section{Discussion and conclusion}

Controversies continue over the causes of banking failure and financial crises in the 1930s. We do not set out in this article to explain experience in countries other than Britain in the interwar years, but it is appropriate to reflect on the various factors put forward to explain variations in experience from country to country. These include differences between universal and specialised banking systems, but '... neither "bankoriented" nor "market-oriented" financial systems escaped the crisis; and it is not easy to say which system proved the more resilient' (Tilly, 1998, p. 23). It is, however, clear that universal banking could produce bad outcomes as, for example, in Italy, where 'connected lending' resulted in poor lending decisions and weak monitoring (Battilossi, 2009).

The question of branch versus unit banking may be another important factor. Branching is generally thought to offer benefits such as greater diversification, resilience to shocks, and ease of co-ordination (Calomiris, 2010). In Britain and Canada, large branch networks were a stabilising factor (Bordo, Rockoff, \& Redish, 1994; Grossman, 1994). But evidence on branch banking elsewhere, including in Germany and the US, is not clear-cut, with the effects of branching on competition and risk-taking behaviour difficult to disentangle (Carlson, 2004; Schnabel, 2009).

Many have argued that central bank policies were inadequate, with the German Reichsbank and the US Federal Reserve ('the Fed') notable examples. Richardson (2007, pp. 643-644) summarises the contrasting views on the Fed's role in the Great Depression. Its failure to inject sufficient high-powered money to offset the reduction in the money stock may have allowed the normal US business cycle to turn into the Great Depression (Bordo, Choudhri, \& Schwartz, 2002; Friedman \& Schwartz, 1963). James is unconvinced: '... the Friedman and Schwartz account is inadequate ... their argument is somewhat slippery as to causality ...' (James, 2001, pp. 76-77). One possible answer is the vulnerability of banks that cleared cheques via correspondents to the collapse of correspondent networks. With widespread unit banking, clearing houses played a prominent role and provided a route by which contagion could be 
spread, which the Fed failed to offset (Richardson, 2007). Richardson \& Van Horn (2009) demonstrate that failures of banks in New York City, the centre of the US money market, resulted from increased regulatory scrutiny rather than contagion from European problems. Calomiris (2010) also rejects the judgement that panic or international contagion contributed to significant bank failures in the US, but is critical of the view that the Fed failed, drawing attention to sector-specific and regional shocks, magnified by the extent of unit banking.

Overall, we suggest that structural weaknesses found in banking systems elsewhere, such as the absence of an effective LOLR, poor governance, the dependence of the main commercial banks on overseas deposits, and the prevalence of unit banking, were absent from Britain. Other factors present in Britain, such as strong liquidity and capital positions, were missing elsewhere. These features were reinforced by the crucial decision to depart from the gold standard, which protected the real economy from undue suffering, allowing Britain to enjoy its strongest-ever upswing from 1932-7, after a recession (not depression) in 1929-32. Britain's escape from the nonmonetary effects identified by Bernanke (1983) helped to ensure that the banking system did not suffer cripplingly high levels of bad debt. To follow the taxonomy of Reinhart \& Rogoff (2009), Britain suffered a currency crisis, but avoided the banking, debt and inflation crises which often accompany this.

The financial system experienced contagion, notably from capital flight by overseas investors during the 1931 exchange-rate crisis, although evidence on the nature and extent of this is unsatisfactory. But evidence of a 'run' on British banks is lacking, the system emerged intact, and we argue was not under serious threat, thereby contributing to the financial and monetary stability which underpin macroeconomic stability. This argument is not new, but the new archival data we present enhance the range and quality of evidence available, and therefore provide more comprehensive support for this view than has been recognised previously.

The increased concentration arising from the amalgamation process which created the Big Five clearing banks had produced powerful and resilient institutions, able to absorb the external shocks of abandonment of the gold standard and the 
Standstill, at a time when severe banking problems were found in many other countries. The Big Five proved sound: they were strongly capitalised and none needed to raise new capital in the 1930s; they had large branch networks and strong earning power; there were no mergers between them or with other banks; and their diversified and liquid balance sheets contrasted, for example, to their German counterparts. These were not universal banks and their much-criticised conservatism and prudence, albeit overstated, helped them to avoid the fate of banks elsewhere, and to ensure that this concentrated banking structure delivered stability.

The British banks which experienced serious problems in the 1930s were those which were smaller and more specialised than the large clearing banks and whose business was relatively undiversified: small clearing banks with large exposures to the Lancashire cotton industry; merchant banks, whose main business was the financing of international trade, much of it Anglo-German; and some British overseas banks, particularly those with heavy dependence on Latin America. Several merchant banks experienced both liquidity and solvency problems, the result of substantial Standstill debt, high leverage, and heavy reliance on foreign deposits. They were effectively insolvent, kept afloat by a mixture of owners' capital, funding from the large clearing banks and the Bank, mergers, and changes to market practice.

The Bank used its full range of powers and persuasion in its active, discreet, and highly discriminatory, support of individual institutions. It often co-opted the large clearing banks into support operations, and the existence of this small group of strong, 'well-behaved' institutions greatly assisted it. Overall, the results were consolidation around the periphery of the clearing banks, but with more fundamental change among the merchant banks and discount houses. The collapse of individual institutions, while not a threat to the British financial system as a whole, would have disrupted the London discount market, still the world's major money market. This would have damaged the status of the City of London as a financial centre, and also British trade, already under pressure from rising trade barriers and falling economic activity in many countries. Thus the Bank acted in its traditional way, fulfilling a role of the type envisaged by Kindleberger \& Aliber (2005, p. 292): 'Domestic lenders of last resort have been established to enhance the stability of the financial system 
although not necessarily of individual financial banks'. However, the Bank did not make a conscious choice to support particular institutions at the expense of abandoning the gold standard. Circumstances meant that the exchange rate was no longer sustainable, but liquidity could be provided to the system.

In the late 2000s crisis hit a highly concentrated British domestic banking system which was threatened by contagion from international problems. There are notable contrasts to the 1930s, when the major commercial banks had adequate capital resources and liquidity, whereas in the 2000s less well-diversified institutions had abandoned robust liquidity positions for alternative models. In the 1930s prudent institutions were able and willing to participate in the Bank's support operations for other financial institutions and in its attempts to maintain the gold standard. This took place within an institutional framework in which there was less transparency than today and detailed rules-based regulation was absent.

We suggest that the 1930s provide an important lesson looking forward. Market concentration in the banking sector may be undesirable from the perspectives of competition and the provision of finance. But within such a system large, welldiversified, and prudent banks, supported by active central banking and the flexibility of a floating exchange rate regime, were able to avoid panic, escaped the need for 'fire sales' of problem assets, and could sustain their capital positions. For smaller, weaker, banks, the existence and effective operation of formal or informal mechanisms ensured that their problems could be managed within this system.

\section{Acknowledgements}

We thank the archivists, past and present, of the major banks: Maria Sienkiewicz, Nicholas Webb and Jessie Campbell (Barclays); Karen Sampson and John Booker (Lloyds Banking Group); Edwin Green and Tina Staples (HSBC); Philip Winterbottom (Royal Bank of Scotland); and Fiona Maccoll (formerly of National Westminster). We are also grateful to Chris Kobrak, Mira Wilkins, and two anonymous reviewers for helpful comments. 


\section{Notes on contributors}

Mark Billings is Lecturer in Accounting and Risk, Nottingham University Business School, UK. Forrest Capie is Emeritus Professor of Economic History, Cass Business School, London. His latest book is The Bank of England, 1950s to 1979 (2010, Cambridge University Press).

\section{References}

Accominotti, O. (2009). London merchant banks, the central European panic and the Sterling crisis of 1931. UC Berkeley and Sciences Po, Paris, mimeo.

Ackrill, M. \& Hannah, L. (2001). Barclays: The business of banking 1690-1996. Cambridge: Cambridge University Press.

Baker, M. \& Collins M. (2010). English commercial banks and organizational inertia: The financing of SMEs, 1944-1960', Enterprise and Society, 11 (1), 65-97.

Battilossi, S. (2009). Did governance fail universal banks? Moral hazard, risk taking, and banking crises in interwar Italy. Economic History Review, 62 (S1), 101134.

Beenstock, M., Capie, F.H., \& Griffiths, B. (1984). Economic recovery in the United Kingdom in the1930s. Panel Paper 23, London: Bank of England.

Bernanke, B.S. (1983). Nonmonetary effects of the financial crisis in the propagation of the Great Depression. American Economic Review, 73 (3), 257-276.

Bernanke, B.S. \& James, H. (1991). The gold standard, deflation and financial crisis in the Great Depression: An international comparison. In R.G. Hubbard (ed.) (1991), Financial markets and financial crises (pp. 33-68). Chicago: University of Chicago Press for NBER.

Billings, M. \& Capie, F.H. (2007). Capital in British banking 1920-1970. Business History, 49 (2), 139-162.

Billings, M. \& Capie, F.H. (2009). Transparency and financial reporting in midtwentieth century British banking. Accounting Forum, 33 (1), 38-53. 
Bordo, M.D., Choudhri, E.U., \& Schwartz, A.J. (2002). Was expansionary monetary policy feasible during the Great Contraction? An examination of the gold standard constraint. Explorations in Economic History, 39 (1), 1-28.

Bordo, M.D., Rockoff, H., \& Redish, A. (1994). The U.S. banking system from a Northern Exposure: Stability versus efficiency. Journal of Economic History, 54 (2), 325-341.

Burk, K. (1989). Morgan Grenfell 1838-1988: The biography of a merchant bank. Oxford: Oxford University Press.

Calomiris, C.W. (2010). Bank failures in theory and history: The Great Depression and other 'contagious' events. In A. Berger, P. Molyneux and J. Wilson (eds.), The Oxford Handbook of Banking (pp. 692-710). Oxford: Oxford University Press.

Capie, F.H. (2002). The emergence of the Bank of England as a mature central bank. In D. Winch \& P.K. O’Brien (eds.), The political economy of British historical experience, 1688-1914. Oxford: Oxford University Press.

Capie, F.H. \& Billings, M. (2001). Profitability in English banking in the twentieth century. European Review of Economic History, 5 (3), 367-401.

Capie, F.H. \& Billings, M. (2004). Evidence on competition in English commercial banking 1920-70. Financial History Review, 11 (1), 69-103.

Capie, F.H., Mills, T.C., \& Wood, G.E. (1986). What happened in 1931? In Capie \& Wood (eds.) (pp. 120-148).

Capie, F.H. \& Webber, A. (1985). A monetary history of the United Kingdom, 18701982: Volume 1 data, sources, methods. London: George Allen \& Unwin.

Capie, F.H. \& Wood, G.E. (eds.) (1986). Financial crises and the world banking system. New York: St. Martin's Press; Basingstoke: Macmillan.

Carlson, M. (2004). Are branch banks better survivors? Evidence from the Depression Era. Economic Inquiry, 42 (1), 111-126.

Collins, M. (1989). The banking crisis of 1878. Economic History Review, 42 (4), 504-27.

Collins, M. (1998). English bank development within a European context, 1870-1939. Economic History Review, 51 (1), 1-24.

Collins, M. \& Baker, M. (2001). English commercial bank liquidity, 1860-1913. Accounting, Business \& Financial History, 11 (2), 171-191. 
Collins, M. \& Baker, M. (2003). Commercial banks and industrial finance in England and Wales, 1860-1913. Oxford: Oxford University Press.

Crafts, N. (2004). Long-run growth. In Floud \& Johnson (eds.) (pp.1-24).

Diaper, S.J. (1986). Merchant banking in the inter-war period: The case of Kleinwort, Sons \& Co. Business History, 28 (4), 55-76.

Eichengreen, B. (1992). Golden fetters: The gold standard and the Great Depression, 1919-1939. New York \& Oxford: Oxford University.

Feinstein, C.H. (1976). Structural tables of national income, expenditure and output of the United Kingdom 1855-1965. Cambridge: Cambridge University Press.

Floud, R. \& Johnson, P. (eds.) (2004). The Cambridge economic history of modern Britain, Vol. II: Economic maturity, 1860-1939. Cambridge: Cambridge University Press.

Forbes, N. (1987). London banks, the German Standstill Agreements, and 'economic appeasement' in the 1930s. Economic History Review, 40 (4), 571-587.

Forbes, N. (2000). Doing business with the Nazis: Britain's economic and financial relations with Germany, 1931-1939. London: Frank Cass.

Friedman, M. \& Schwartz, A.J. (1963). A monetary history of the United States 18671960. Princeton: Princeton University Press.

Grossman, R.S. (1994). The shoe that didn't drop: Explaining banking stability during the Great Depression. Journal of Economic History, 54 (3), 654-682.

Hatton, T.J. (2004). Unemployment and the labour market, 1870-1939. In Floud \& Johnson (eds.) (pp. 344-373).

Holmes, A.R. \& Green, E. (1986). Midland: 150 Years of banking business. London: B.T. Batsford.

Howson, S. (1980). The management of Sterling 1932-39. Journal of Economic History, 40 (1), 53-60.

James, H. (1992). Financial flows across frontiers during the interwar depression. Economic History Review, 45 (3), 594-613.

James, H. (2001). The end of globalization: Lessons from the Great Depression. Cambridge, Mass.: Harvard University Press.

Jones, G. (1993). British multinational banking 1830-1990. Oxford: Oxford University Press. 
Jonker, J. \& van Zanden, J.L. (1995). Method in the madness? Banking crises between the wars, an international comparison. In C.H. Feinstein, (ed.), Banking, currency and finance in Europe between the wars (pp. 76-93). Oxford: Clarendon Press.

Kindleberger, C.P. (1986). The world in depression, 1929-1939. Second edition, Berkeley \& Los Angeles: University of California Press.

Kindleberger, C.P. \& Aliber, R.Z. (2005). Manias, panics and crashes: A history of financial crises. Fifth edition, Hoboken, NJ: John Wiley \& Sons.

Kobrak, C. (2009). Family finance: Value creation and the democratization of crossborder governance. Enterprise and Society, 10 (1), 38-89.

Kynaston, D. (1999). The City of London: Volume III, Illusions of gold 1914-1945. London: Chatto \& Windus.

Munn, C.W. (1988). Clydesdale Bank: The first 150 years. London \& Glasgow: William Collins, Sons \& Co. Limited.

Newton, L. (2003). Government, the banks and industry in inter-war Britain. In T. Gourvish (ed.), Business and politics in Europe, 1900-1970: Essays in Honour of Alice Teichova (pp. 145-168). Cambridge: Cambridge University Press.

Rajan, R.G. \& Zingales, L. (2003). The great reversals: The politics of financial development in the twentieth century. Journal of Financial Economics, 69 (1), 5-50.

Reinhart, C.M. \& Rogoff, K.S. (2009). This time is different: Eight centuries of financial folly. Oxford and Princeton, NJ: Princeton University Press.

Richardson, G. (2007). The check is in the mail: Correspondent clearing and the collapse of the banking system, 1930 to 1933. Journal of Economic History, 67 (3), 643-671.

Richardson, G. \& Van Horn, P. (2009). Intensified regulatory scrutiny and bank distress in New York City during the Great Depression. Journal of Economic History, 69 (2), 446-465.

Roberts, R. (1992). Schroders: Merchants \& bankers. London \& Basingstoke: Macmillan.

Ross, D.M. (1996). Commercial banking in a market-oriented financial system: Britain between the wars. Economic History Review, 44 (2), 314-335. 
Saville, R. (1996). Bank of Scotland, a history, 1695-1944. Cambridge: Cambridge University Press. Edinburgh: Edinburgh University Press.

Sayers, R.S. (1976). The Bank of England 1891-1944. Cambridge: Cambridge University Press.

Schnabel, I. (2009). The role of liquidity and implicit guarantees in the German twin crisis of 1931. Journal of International Money and Finance, 28 (1), 1-25.

Schwartz, A.J. (1986). Real and pseudo-financial crises. In Capie \& Wood (eds.) (pp. 11-31).

Sheppard, D.K. (1971). The growth and role of UK financial institutions 1880-1962. London: Methuen \& Co.

Tilly, R. (1998). Universal banking in historical perspective. Journal of Institutional and Theoretical Economics, 154 (1), 7-32.

Truptil, R.J. (1936). British banks and the London money market. London: Jonathan Cape.

Tuke, A.W. \& Gillman, R.J.H. (1972). Barclays Bank Limited 1926-1969. London: Barclays Bank Limited.

Williams, D. (1963). London and the 1931 financial crisis. Economic History Review, 15 (3), 513-528.

Williams Deacon's (1971). Williams Deacon's 1771-1970. Manchester: Williams Deacon's Bank Limited.

Williamson, P. (1992). National crisis and National Government: British politics, the economy and empire, 1926-1932. Cambridge: Cambridge University Press.

Winton, J.R. (1982). Lloyds Bank 1918-1969. Oxford: Oxford University Press. 
Table 1: Support operations in British banking, 1927-39

\begin{tabular}{|c|c|c|c|c|c|}
\hline & date & $\begin{array}{l}\text { amount of } \\
\text { support }(£ 000 s)\end{array}$ & $\begin{array}{l}\text { amount of } \\
\text { loss }(£ 000 s)\end{array}$ & $\begin{array}{l}\text { support provided/loss } \\
\text { suffered by }\end{array}$ & source \\
\hline Anglo International Bank & $1927-43$ & 1,000 & 1,600 & $\mathrm{BoE}$ & Jones, 1993, pp. 230-231 \\
\hline \multirow[t]{4}{*}{ Anglo-South American Bank ${ }^{1}$} & $1931-6$ & $5,000-8,500$ & $\begin{array}{l}4,568, \text { of } \\
\text { which BoE } \\
2,351\end{array}$ & $\begin{array}{l}\text { BoE and Big Five excluding } \\
\text { Lloyds }\end{array}$ & $\begin{array}{l}\text { Jones, } 1993 \text {, pp. } 240-242 \text {; Sayers, } 1976 \text {, } \\
\text { pp. } 263-267\end{array}$ \\
\hline & & & 800 & Westminster & RBSGA, WES/1177/96 \\
\hline & & & c. 500 & Barclays) & Holmes \& Green, 1986, p. 186 \\
\hline & & & c. 500 & Midland) & \\
\hline \multirow[t]{3}{*}{$\begin{array}{l}\text { Banca Italo-Britannica/British-Italian } \\
\text { Corporation }\end{array}$} & 1929-30 & 5,100 & $\begin{array}{l}3,861 \text { to } \\
5,347\end{array}$ & $\begin{array}{l}\text { Lloyds, National Provincial, } \\
\text { Westminster }\end{array}$ & Jones, 1993, pp. 231-234 \\
\hline & & & 1,080 & Lloyds & $\begin{array}{l}\text { Winton, 1982, pp. 57-9; LGA, Winton } \\
\text { research file 'Investments' }\end{array}$ \\
\hline & & 250 & 250 & $\mathrm{BoE}$ & Sayers, 1976 , pp. $261-262$ \\
\hline \multirow[t]{4}{*}{ British Overseas Bank $^{2}$} & 1938 & 1,000 & 300 & $\mathrm{BoE})$ & Jones, 1993 , pp. 243-244 \\
\hline & & 750 & & National Provincial) & \\
\hline & & 250 & & Union Bank of Scotland) & \\
\hline & & & c. 400 & William’s Deacons & William's Deacons, 1971, p. 161 \\
\hline Cox \& Co. ${ }^{3}$ & 1929 & $\begin{array}{l}900 \mathrm{BoE} \\
\text { guarantees }\end{array}$ & 267 & $\mathrm{BoE}$ & Jones, 1993, p. 240; Sayers, 1976, p. 242 \\
\hline Glyn, Mills ${ }^{4}$ & 1939 & - & - & - & \\
\hline Hambros (A) & 1932 & 100 & - & $\mathrm{BoE}$ & $\begin{array}{l}\text { Kynaston, 1999, p. 359; Sayers, 1976, p. } \\
531\end{array}$ \\
\hline
\end{tabular}




\begin{tabular}{|c|c|c|c|c|c|}
\hline & date & $\begin{array}{l}\text { amount of } \\
\text { support (£000s) }\end{array}$ & $\begin{array}{l}\text { amount of } \\
\text { loss }(£ 000 s)\end{array}$ & $\begin{array}{l}\text { support provided/loss } \\
\text { suffered by }\end{array}$ & source \\
\hline Higginson \& Co. (A) & 1932 & 340 & - & $\mathrm{BoE}$ & $\begin{array}{l}\text { Kynaston, 1999, p. 360; Sayers, 1976, p. } \\
531\end{array}$ \\
\hline F. Huth \& Co. (A) ${ }^{2}$ & early 1930s & - & 1,000 & $\mathrm{BoE}$ & $\begin{array}{l}\text { Jones, 1993, pp. 243-244; Sayers, 1976, p. } \\
270\end{array}$ \\
\hline \multirow[t]{2}{*}{ Kleinwort, Sons \& Co. (A) } & 1931 & $\begin{array}{l}\text { 3,250 (repaid by } \\
\text { Sept. 1932) }\end{array}$ & - & Westminster & Diaper, 1986, p. 69 \\
\hline & 1939 & $\begin{array}{l}1,000 \text { (repaid } \\
1940)\end{array}$ & - & Westminster & Diaper, 1986, p. 71 \\
\hline Lazard (A): fraud in Brussels office & July 1931 & $\begin{array}{l}3,500 \text { (repaid over } \\
\text { seven years) }\end{array}$ & 6,000 & $\begin{array}{l}\text { BoE) } \\
\text { Lazard) }\end{array}$ & $\begin{array}{l}\text { Kynaston, 1999, p. 228; Sayers, 1976, pp. } \\
530-531\end{array}$ \\
\hline Lazard (A): 'problems in Paris' & 1932 & 2,000 & & $\begin{array}{l}\text { in equal shares: BoE and } \\
\text { National Provincial }\end{array}$ & Kynaston, 1999, p. 360 \\
\hline $\begin{array}{l}\text { Lloyds and National Provincial Foreign } \\
\text { Bank }\end{array}$ & $1931-9$ & $\begin{array}{l}1,500 \text { guarantees/ } \\
\text { payments to } \\
\text { recapitalise }\end{array}$ & - & Lloyds, National Provincial & RBSGA, LBI/14/2072; Jones, 1993, p. 143 \\
\hline J. Henry Schröder \& Co. (A) & $\begin{array}{l}1936 \\
1939\end{array}$ & $\begin{array}{l}1,000 \text { (repaid) } \\
1,000\end{array}$ & - & Westminster & Roberts, 1992, p. 266 \\
\hline Williams Deacon's 5 & 1929-38 & 4,000 max. & 3,212 & $\mathrm{BoE}$ & Sayers, 1976 , p. 258 \\
\hline
\end{tabular}

Notes:

Big Five = Barclays, Lloyds, Midland, National Provincial and Westminster banks

$\mathrm{BoE}=$ Bank of England

$\mathrm{A}=$ member of the Accepting Houses' Committee of merchant banks 
$1=$ merged with Bank of London and South America in 1936

$2=$ F. Huth \& Co. taken over by British Overseas Bank in 1936

$3=$ taken over by Lloyds 1929

$4=$ taken over by Royal Bank of Scotland in 1939

$5=$ taken over by Royal Bank of Scotland in 1930; losses to BoE reflect losses on pre-takeover lending by Williams Deacon's

'Support' usually took the form of loans.

For comparison, when the City of Glasgow Bank failed in 1878, the shortfall to the shareholders with unlimited liability was £5.2 million (Collins, 1989, p. 504), equivalent to $£ 9.1$ million at 1931 prices and $£ 471$ million at end-2009 prices. $£ 1$ million in 1931 is equivalent to approximately $£ 52$ million at end-2009. 
Table 2: Banks’ deposits at financial year-end dates, 1930-2

\begin{tabular}{|c|c|c|c|c|}
\hline \multirow[b]{2}{*}{ Big Five clearing banks } & \multirow{2}{*}{$\begin{array}{c}\begin{array}{c}\text { deposits } \\
\text { (£m) }\end{array} \\
1930\end{array}$} & \multicolumn{3}{|c|}{$\begin{array}{c}\text { index of deposits, } 1930 \\
=100\end{array}$} \\
\hline & & 1930 & 1931 & 1932 \\
\hline Barclays & 347.9 & 100 & 96 & 109 \\
\hline Lloyds & 364.6 & 100 & 92 & 105 \\
\hline Midland & 399.6 & 100 & 90 & 105 \\
\hline National Provincial & 291.5 & 100 & 90 & 100 \\
\hline Westminster & 291.6 & 100 & 93 & 102 \\
\hline \multicolumn{5}{|l|}{ other main commercial banks } \\
\hline District & 52.4 & 100 & 96 & 108 \\
\hline Martins & 78.6 & 100 & 97 & 109 \\
\hline Williams Deacon's & 32.0 & 100 & 91 & 106 \\
\hline \multicolumn{5}{|l|}{ Scottish banks } \\
\hline Bank of Scotland & 32.3 & 100 & 101 & 96 \\
\hline Clydesdale & 30.2 & 100 & 93 & 106 \\
\hline Royal Bank of Scotland & 50.4 & 100 & 98 & 111 \\
\hline \multicolumn{5}{|l|}{ British overseas banks } \\
\hline Anglo-South American & 49.8 & 100 & 82 & 51 \\
\hline Bank of Australasia & 34.2 & 100 & 107 & 111 \\
\hline Bank of London and South America & 39.4 & 100 & 87 & 105 \\
\hline Barclays DCO & 62.7 & 100 & 109 & 114 \\
\hline Chartered & 40.8 & 100 & 95 & 107 \\
\hline Hongkong & 50.6 & 100 & 110 & 115 \\
\hline \multicolumn{5}{|l|}{ merchant banks } \\
\hline Baring Brothers \& Co. & 17.6 & 100 & 100 & 99 \\
\hline Erlangers & 4.1 & 100 & 30 & 41 \\
\hline Hambros & 18.4 & 100 & 58 & 58 \\
\hline S. Japhet \& Co. & 6.2 & 100 & 37 & 32 \\
\hline J. Henry Schröder \& Co. & 8.8 & 100 & 50 & 38 \\
\hline \multicolumn{5}{|l|}{ aggregate data } \\
\hline UK banks & $2,396.0$ & 100 & 93 & 105 \\
\hline Joint stock banks of England and Wales & $1,976.8$ & 100 & 92 & 104 \\
\hline London clearing banks & $1,903.4$ & 100 & 92 & 104 \\
\hline London clearing banks, average of monthly statements & $1,801.0$ & 100 & 98 & 99 \\
\hline
\end{tabular}

Sources: authors calculations. Bank of Scotland: Saville, 1996, p. 962, Table A8; Clydesdale Bank: Munn, 1988, p. 340; British overseas banks: Jones, 1993, Appendix 5; merchant banks except Schroders: Truptil, 1936, pp. 336-337, 339, Appendices III and V; Schroders: Roberts, 1992, p. 530, Appendix IV (i); other banks: annual reports; aggregate data: Sheppard, 1971: pp. 116-119, Tables (A) 1.1, 1.2, pp. 130-133, Tables (A) $1.8,1.9$, pp. 138-139, Table (A) 1.13 .

Notes:

'Deposits' represents 'Deposit and other accounts' at financial year-end dates, except for 'average of monthly statements' for London clearing banks. The financial year- 
end date is 31 December for all banks except: Anglo-South American (31 October); Bank of Australasia (30 June); Barclays DCO and Bank of London and South America (30 September); Hambros (31 March in following year); Hongkong (31 August); Royal Bank of Scotland (11 October 1930, 10 October 1931, 8 October 1932).

Table 3: Fluctuations in weekly deposits, Westminster and District banks, 1931

\begin{tabular}{lcc}
\hline & Westminster & District \\
\hline annual average & 100 & 100 \\
standard deviation & 3.41 & 2.79 \\
minimum & 95.02 & 95.67 \\
maximum & 109.92 & 108.16 \\
date of minimum & 24 September 1931 & 8 April 1931 \\
date of maximum & 1 January 1931 & 21 January 1931 \\
\hline
\end{tabular}

data are summarised for 'Deposits and other accounts'

Source: authors' calculations from weekly balance sheet data, RBSGA, WES/561 and DIS/102 
Table 4: Fluctuation in aggregate deposits of London clearing banks, 1926-36

\begin{tabular}{|c|c|c|c|c|c|c|c|c|c|c|c|c|}
\hline & 1926 & 1927 & 1928 & 1929 & 1930 & 1931 & 1932 & 1933 & 1934 & 1935 & 1936 & mean \\
\hline January & 100.6 & 101.1 & 101.0 & 102.6 & 100.2 & 106.4 & 95.9 & 101.6 & 102.1 & 99.2 & 97.7 & 100.8 \\
\hline February & 98.7 & 98.7 & 98.2 & 100.8 & 97.3 & 103.4 & 92.8 & 100.3 & 100.3 & 97.8 & 95.8 & 98.5 \\
\hline March & 97.6 & 97.5 & 96.8 & 98.7 & 95.5 & 100.2 & 93.8 & 98.6 & 97.3 & 96.2 & 95.1 & 97.0 \\
\hline April & 97.8 & 98.0 & 97.8 & 98.9 & 97.2 & 98.6 & 94.1 & 98.9 & 98.5 & 97.1 & 97.2 & 97.6 \\
\hline May & 97.7 & 98.5 & 97.7 & 98.3 & 98.8 & 98.7 & 95.1 & 99.6 & 98.8 & 98.1 & 98.6 & 98.2 \\
\hline June & 100.2 & 100.5 & 100.1 & 100.4 & 101.4 & 101.2 & 98.8 & 101.3 & 99.4 & 100.2 & 100.6 & 100.4 \\
\hline July & 101.1 & 100.4 & 101.1 & 100.9 & 101.7 & 101.6 & 101.0 & 101.1 & 99.4 & 101.0 & 101.3 & 101.0 \\
\hline August & 100.4 & 99.6 & 100.1 & 99.8 & 100.2 & 99.1 & 101.0 & 100.3 & 98.7 & 100.7 & 101.4 & 100.1 \\
\hline September & 99.7 & 99.5 & 100.2 & 99.5 & 100.0 & 97.2 & 104.4 & 100.3 & 98.8 & 101.3 & 101.9 & 100.3 \\
\hline October & 101.3 & 102.0 & 101.3 & 100.1 & 101.5 & 97.9 & 106.0 & 99.9 & 100.5 & 101.9 & 102.9 & 101.4 \\
\hline November & 101.2 & 101.1 & 101.3 & 99.4 & 102.1 & 96.9 & 106.3 & 98.8 & 101.6 & 102.0 & 103.2 & 101.3 \\
\hline December & 103.7 & 103.1 & 104.4 & 100.6 & 104.2 & 98.7 & 111.0 & 99.4 & 104.8 & 104.6 & 104.5 & 103.5 \\
\hline minimum & 97.6 & 97.5 & 96.8 & 98.3 & 95.5 & 96.9 & 92.8 & 98.6 & 97.3 & 96.2 & 95.1 & 96.6 \\
\hline maximum & 103.7 & 103.1 & 104.4 & 102.6 & 104.2 & 106.4 & 111.0 & 101.6 & 104.8 & 104.6 & 104.5 & 104.6 \\
\hline standard deviation & 1.8 & 1.7 & 2.1 & 1.2 & 2.5 & 2.8 & 5.9 & 1.0 & 2.0 & 2.4 & 3.1 & 2.4 \\
\hline
\end{tabular}

Annual average in each year $=100$.

Source: authors' calculations from Capie \& Webber, 1985, Table III.(4), p. 444 
Table 5: Composition of joint-stock banks' aggregate balance sheets: percentages represented by main asset categories, 1860-1913, 1920-39

\begin{tabular}{ccccc}
\hline & $\begin{array}{c}\text { cash and near- } \\
\text { cash }\end{array}$ & $\begin{array}{c}\text { bills } \\
\text { discounted }\end{array}$ & investments & advances \\
\hline Decade & & & & \\
$1860-69$ & 13 & 31 & 11 & 45 \\
$1870-79$ & 17 & 27 & 12 & 48 \\
$1880-89$ & 21 & 26 & 17 & 38 \\
$1890-99$ & 22 & 17 & 21 & 42 \\
$1900-09$ & 24 & 11 & 18 & 46 \\
$1910-13$ & 26 & 13 & 16 & 45 \\
$1920-29$ & 21 & 13 & 20 & 44 \\
$1930-39$ & 21 & 11 & 30 & 36 \\
& & & & \\
Year & & 14 & 19 & 43 \\
1930 & 22 & 12 & 21 & 44 \\
1931 & 21 & 16 & 28 & 34 \\
1932 & 20 & & & \\
\hline
\end{tabular}

Sources: authors' calculations from: Collins \& Baker, 2001, p. 183, Table 2 (18601913 decadal averages); Sheppard, 1971, pp. 116-117, Table (A) 1.1 (1920-29 and 1930-39 decadal averages, and years 1930-32) 
Table 6: 'True' capital as percentage of total assets, 1930-39

\begin{tabular}{|c|c|c|c|c|c|c|c|}
\hline year & Barclays & Lloyds & Martins & Midland & $\begin{array}{c}\text { National } \\
\text { Provincial }\end{array}$ & Westminster & mean \\
\hline 1930 & 8.7 & $\mathrm{n} / \mathrm{a}$ & $\mathrm{n} / \mathrm{a}$ & 8.1 & 7.8 & 9.7 & 8.8 \\
\hline 1931 & 9.1 & $\mathrm{n} / \mathrm{a}$ & $\mathrm{n} / \mathrm{a}$ & 9.1 & 8.2 & 9.7 & 8.6 \\
\hline 1932 & 7.8 & 7.4 & 10.9 & 7.6 & 7.1 & 8.9 & 8.5 \\
\hline 1933 & 7.9 & 7.7 & 11.7 & 8.3 & 7.2 & 9.0 & 8.7 \\
\hline 1934 & 7.9 & 7.9 & 11.5 & 8.3 & 7.3 & 9.4 & 8.7 \\
\hline 1935 & 7.4 & 7.7 & 10.9 & 7.9 & $\mathrm{n} / \mathrm{a}$ & 9.3 & 8.5 \\
\hline 1936 & 7.2 & 7.9 & 10.9 & 7.5 & $\mathrm{n} / \mathrm{a}$ & 8.5 & 8.3 \\
\hline 1937 & 7.4 & 7.4 & 10.6 & 7.8 & 7.7 & 8.5 & 8.3 \\
\hline 1938 & 7.1 & 7.6 & 10.1 & 8.4 & 8.2 & 9.1 & 8.0 \\
\hline 1939 & 6.7 & 7.0 & $\mathrm{n} / \mathrm{a}$ & 8.2 & 7.6 & 7.8 & 7.2 \\
\hline
\end{tabular}

$\mathrm{n} / \mathrm{a}=$ not available

Sources: authors' calculations from published accounts and archival sources: BGA: Barclays, 3/336, Martins, 38/569-579; LGA: research file of the bank's historian, Winton: 'Capital, Reserves, and Dividends'; HSBC Holdings plc, Group Archives, London (HSBCGA): Midland, 227/3, accounts volumes for relevant years (described as 'black books'); RBSGA: National Provincial, volumes 9452 \& 9480, Westminster, 13365 \& 13366. 
Table 7: Bad debt experience, 1920-39

\begin{tabular}{|c|c|c|c|c|c|c|c|c|c|c|c|c|}
\hline bank & $\begin{array}{l}\text { 1920-29 } \\
\text { average }\end{array}$ & $\begin{array}{l}\text { 1930-39 } \\
\text { average }\end{array}$ & 1930 & 1931 & 1932 & 1933 & 1934 & 1935 & 1936 & 1937 & 1938 & 1939 \\
\hline \multicolumn{13}{|c|}{ total bad debt provisions } \\
\hline Barclays & 1.7 & 3.1 & 2.7 & 2.9 & 3.9 & 4.0 & 4.0 & 3.9 & 3.1 & 2.8 & 2.7 & 1.5 \\
\hline Martins & 3.6 & 6.6 & 5.0 & 5.0 & 9.7 & 11.5 & 7.9 & 7.4 & 5.3 & 4.8 & 3.9 & 5.1 \\
\hline Midland & 2.7 & 4.0 & 3.7 & 4.0 & $\mathrm{n} / \mathrm{a}$ & 4.5 & 4.6 & 4.2 & 3.9 & 3.7 & 3.9 & 3.6 \\
\hline National Provincial & 3.2 & 4.0 & 3.5 & 4.3 & 4.9 & 5.5 & 5.7 & $\mathrm{n} / \mathrm{a}$ & $\mathrm{n} / \mathrm{a}$ & 3.0 & 2.6 & 2.1 \\
\hline Westminster & $\mathrm{n} / \mathrm{a}$ & $\mathrm{n} / \mathrm{a}$ & $\mathrm{n} / \mathrm{a}$ & $\mathrm{n} / \mathrm{a}$ & $\mathrm{n} / \mathrm{a}$ & $\mathrm{n} / \mathrm{a}$ & $\mathrm{n} / \mathrm{a}$ & $\mathrm{n} / \mathrm{a}$ & $\mathrm{n} / \mathrm{a}$ & $\mathrm{n} / \mathrm{a}$ & $\mathrm{n} / \mathrm{a}$ & 5.2 \\
\hline \multicolumn{13}{|l|}{ bad debt charge } \\
\hline Barclays & 0.5 & 0.3 & 0.6 & 0.6 & 0.7 & 0.3 & 0.3 & 0.2 & 0.0 & 0.1 & 0.1 & 0.5 \\
\hline Lloyds & 0.3 & 0.2 & 0.4 & 0.5 & 0.6 & 0.1 & 0.0 & 0.1 & 0.1 & 0.0 & 0.0 & 0.1 \\
\hline Martins & 0.4 & 0.8 & 0.6 & 0.6 & 2.2 & 1.7 & 1.7 & 0.4 & 0.0 & -0.2 & -0.2 & 1.0 \\
\hline Midland & 0.6 & 0.5 & 0.3 & 0.3 & 0.4 & 0.6 & 1.4 & 0.7 & 0.5 & 0.4 & 0.2 & 0.3 \\
\hline National Provincial & 0.4 & 0.8 & 1.4 & 1.1 & 0.3 & 0.6 & 0.7 & $\mathrm{n} / \mathrm{a}$ & $\mathrm{n} / \mathrm{a}$ & $\mathrm{n} / \mathrm{a}$ & $\mathrm{n} / \mathrm{a}$ & $\mathrm{n} / \mathrm{a}$ \\
\hline Westminster & 0.6 & 0.5 & 1.0 & 0.9 & 0.6 & 0.4 & 0.0 & 0.0 & 0.0 & 0.9 & 0.6 & 0.9 \\
\hline \multicolumn{13}{|l|}{ bad debt write-offs } \\
\hline Barclays & 0.5 & 0.6 & 0.4 & 0.8 & 1.1 & 0.2 & 0.2 & 0.3 & 0.7 & 0.2 & 0.2 & 1.8 \\
\hline Westminster & $\mathrm{n} / \mathrm{a}$ & 0.5 & $\mathrm{n} / \mathrm{a}$ & 0.4 & 0.3 & 1.2 & 0.5 & 0.3 & 0.1 & 0.4 & 0.8 & 0.3 \\
\hline
\end{tabular}

$\mathrm{n} / \mathrm{a}=$ not available

Source: as Table 6, plus: RBSGA: National Provincial, volume 9451.

Note: see text for definitions of the three measures of bad debt experience. 
Table 8: Standstill exposures, 1931 and 1939

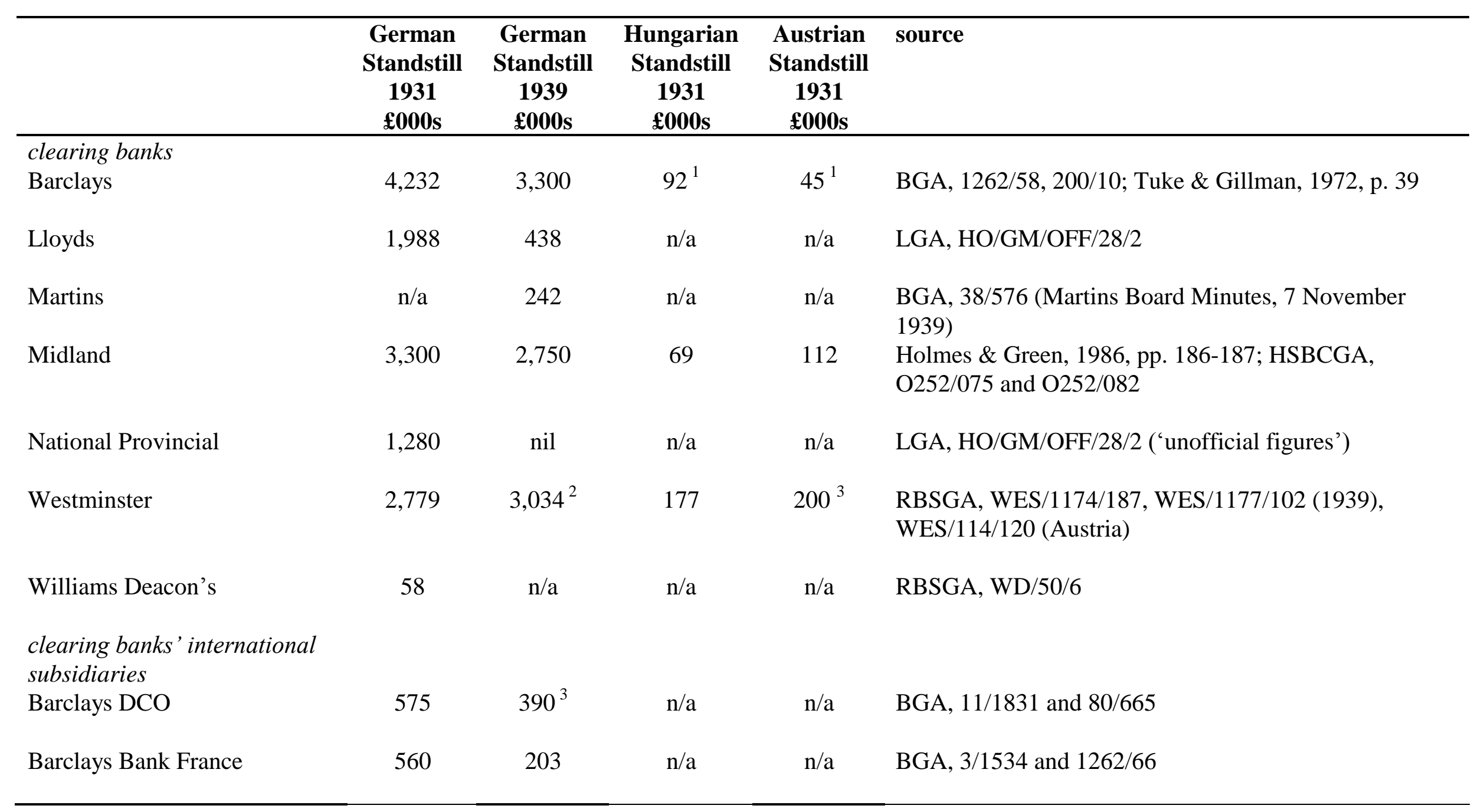




\begin{tabular}{|c|c|c|c|c|c|}
\hline & $\begin{array}{c}\text { German } \\
\text { Standstill } \\
1931 \\
£ 000 s\end{array}$ & $\begin{array}{c}\text { German } \\
\text { Standstill } \\
1939 \\
£ 000 s\end{array}$ & $\begin{array}{c}\text { Hungarian } \\
\text { Standstill } \\
1931 \\
\text { £000s }\end{array}$ & 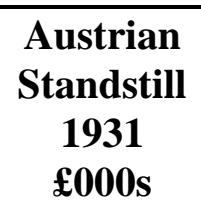 & source \\
\hline Westminster Foreign Bank & 1,021 & nil $^{2}$ & $\mathrm{n} / \mathrm{a}$ & $\mathrm{n} / \mathrm{a}$ & RBSGA, WES/1174/187 \\
\hline
\end{tabular}

Notes:

$\mathrm{n} / \mathrm{a}=$ not available

$1=$ at May 1932

$2=$ Westminster Foreign Bank's exposures were taken over by its parent, Westminster, in 1935 (RBSGA, WES/1174/187)

$3=$ at August 1938

$4=$ Lloyds and National Provincial banks each owned 50\%

$5=$ deposits held with German banks at end-1937

The 1931 figures are those for the date closest to the inception of the Standstill. The 1939 figures are those for the date closest to the outbreak of war. There are minor inconsistencies between the figures shown and those included in a schedule found on a Foreign Office file (National Archives, Kew, London, FO944/394), which shows balances outstanding at 3 September 1939. 


\section{Notes}

1 Austria £1.2 million and Hungary £5.5 million at the end of 1931: The Royal Bank of Scotland Group plc, Group Archives, London (RBSGA), WES/1174/120.

2 Barclays Bank PLC, Group Archives, Manchester (BGA), Martins Board Minutes, 22 September 1931.

3 RBSGA, WES/1174/187, 'Report of Chief General Manager' to Board meeting of 29 September 1936.

${ }^{4}$ RBSGA, WES/1174/249.

${ }^{5}$ BGA, 140/65, 'Records of Advances Made, Mr. Murrell's Section'.

${ }^{6}$ Lloyds Banking Group plc, Group Archives, London (LGA), HO/D/BOA/MIN/36 \& 37, Main Board Minutes 1931.

${ }^{7}$ LGA, HO/D/BOA/MIN/36, 28 July 1931.

${ }^{8}$ RBSGA, LBI/14/2072; LBI/14/2078, pro-forma balance sheet. 